Klinička psihologija 12 (2019), 1-2, 67-81

Izvorni znanstveni rad - UDK

DOI: 10.21465/2019-KP-1-2-0004

\title{
KVALITETA ŽIVOTA KOD PACIJENTICA OBOLJELIH OD RAKA DOJKE: ULOGA ALEKSITIMIJE I OBRAMBENIH MEHANIZAMA
}

\author{
Dora Popović \\ Fakultet hrvatskih studija, Sveučilište u Zagrebu \\ Borongajska 83d, 10000 Zagreb \\ dora.popovic123@gmail.com \\ Jelena Žipovski \\ Fakultet hrvatskih studija, Sveučilište u Zagrebu \\ Borongajska 83d, 10000 Zagreb \\ jelena_zipovski@hotmail.com \\ Lovorka Brajković \\ Fakultet hrvatskih studija, Sveučilište u Zagrebu \\ Borongajska 83d, 10000 Zagreb \\ lbrajkov1@hrstud.hr
}

\begin{abstract}
Sažetak
U procesu liječenja, pacijentice koje boluju od raka dojke, uz otežano fizičko funkcioniranje kao posljedice prirode same bolesti, nerijetko doživljavaju i psihičke tegobe zbog brige oko vlastite dijagnoze i njenih ishoda. Glavni je cilj ovog istraživanja utvrditi kvalitetu života i određene psihičke aspekte pacijentica oboljelih od raka dojke. $U$ istraživanju su sudjelovale 44 pacijentice koje su pomoć potražile u različitim klinikama i udrugama na području grada Zagreba. Sudionice su rješavale upitnik samoprocjene koji se sastojao od sociodemografskog dijela i sljedećih kliničkih skala: Upitnika zdravstvenog statusa (SF-36), Torontske skale aleksitimije (TAS) i Upitnika obrambenih mehanizama (DSQ-40). Rezultati su pokazali sniženu kvalitetu života kod pacijentica koje boluju od raka dojke, a hijerarhijskom regresijskom analizom utvrđeno je kako su aleksitimija i zreli obrambeni stilovi dobar prediktor u utvrđivanju percepcije općeg zdravlja pacijentica. Uočena je veća učestalost korištenja različitih nezrelih obrambenih mehanizama kod pacijentica s aleksitimijom. U raspravi su dana detaljnija obrazloženja ovih rezultata i implikacije za daljnja istraživanja.
\end{abstract}

Ključne riječi: rak dojke, zdravstvena kvaliteta života, aleksitimija, obrambeni mehanizmi 


\section{UVOD}

Rak dojke jedna je od najčešćih dijagnoza karcinoma u svijetu te je prema statističkim podatcima Svjetskog fonda za istraživanje karcinoma WCRFI (World Cancer Research Fund International, 2014) drugi najzastupljeniji oblik karcinoma u svijetu. U Republici Hrvatskoj rezultati su još nepovoljniji te je rak dojke najčešći oblik karcinoma uz ukupnu prevalenciju od $26 \%$ među svim pacijentima koji boluju od karcinoma. Opća incidencija raka dojke u Hrvatskoj je 119,2 bolesnika na 100 000 ljudi, što u usporedbi sa statističkim podacima Europske unije predstavlja veću incidenciju dijagnoze od europskog prosjeka (Hrvatski zavod za javno zdravstvo, 2016). Osim brojnih poteškoća koje dolaze kao posljedica tijeka liječenja, sam proces dijagnostike i liječenja ima nebrojene utjecaje na kvalitetu života pacijentica (Perry, Kowalski, Chang, 2007). Istraživanje autora Fortner, Stepanski, Wang, Kasprowitz i Durrence (2002) implicira kako pacijentice s rakom dojke pokazuju niže rezultate na skali subjektivne procjene vitalnosti, emocionalnih aspekata kvalitete života, fizičkog funkcioniranja i subjektivne procjene mentalnog zdravlja. Autori navode i probleme u spavanju te niži stupanj subjektivno procijenjenog općeg funkcioniranja te naglašavaju važnost emocionalne i socijalne podrške pacijenticama od strane sustava liječenja u procesu tretmana (Fortner i sur., 2002).

U prilog takvim rezultatima ide i novije istraživanje koje su proveli Mosher, Johnson, Dickler, Norton, Massie i DuHamel (2013) koje na uzorku pacijentica s metastatičkim rakom dojke, navodeći narušenost kvalitete života u sferama fizičkog i emocionalnog spektra te socijalnog funkcioniranja, poremećene slike o vlastitom tijelu te općenito teške prilagodbe na novootkriveno zdravstveno stanje i njegov tijek.

Aleksitimija kao vrsta kvalitativnog poremećaja afektivnog funkcioniranja se očituje u nemogućnosti pojedinca da prepozna, opiše te izrazi vlastite emocije (Begić, 2014). Može je se promatrati kao multidimenzionalni koncept koji se pojavljuju ponajviše na kognitivnoj i afektivnoj razini (De Vries, Forni, Voellinger i Stiefel, 2012) i nije često istraživan konstrukt. Lumley, Neely i Burger (2007) navode kako je osim nemogućnosti izražavanja vlastitih emocionalnih doživljaja kod aleksitimičnih pojedinaca prisutna izrazita osjetljivost na simptome promjene zdravstvenog stanja. Tako su pojedinci s povišenom razinom aleksitimičnih simptoma zamijetili i najmanje promjene $u$ tjelesnoj temperaturi i općenito promjenama u vlastitom organizmu, objašnjavajući da dolazi do adaptacije na tjelesne promjene zbog nemogućnosti fokusiranja na emocionalno izražavanje (Lumley i sur., 2007). Longitudinalno istraživanje Porcelli, Tulipani, Maiello, Cilenti i Todarello (2007) pacijenata s karcinomom je uputilo na visoku učestalost aleksitimije, posebice ističu pacijentice s rakom dojke. Isto istraživanje zamjećuje višu ambivalentnost u emocionalnoj identifikaciji i ekspresiji samih emocionalnih izraza naspram drugih. Istraživanja upućuju na to kako pacijentice s karcinomom dojke karakteristično upotrebljavaju strategiju kognitivnog izbjegavanja kao mehanizam obrane koji obilježava distanciranost od okoline i strah od odbijanja te nespremnost na suočavanje 
s trenutačnim problemom (Stanton i Snider, 1993). Osim kognitivnog izbjegavanja uočena je i velika tendencija prema uporabi obrambenog mehanizma traženja socijalne podrške koji je uz mehanizam optimizma pokazao statistički značajnu povezanost s pozitivnim ishodom bolesti za razliku od mehanizma kognitivnog izbjegavanja (Stanton i Snider, 1993). U prilog navedenim rezultatima idu i nalazi Cooper i Faragher (1993) koji uz obrambeni mehanizam kognitivnog izbjegavanja implicira i tendenciju prema negiranju cjelokupne dijagnoze i same simptomatike uz internalizaciju problema s kojima se susreću te osobnu izolaciju od prijeko potrebne socijalne podrške. Uz navedene rezultate, pacijentice su upotrebljavale značajno manji broj zrelih obrambenih mehanizama uz nesklonost prema izražavanju emocija koja je pokazana statistički značajno povezana s negativnim ishodom bolesti (Cooper i Faragher, 1993). Na mehanizme se općenito može gledati kao na posljedice različitih stanja i situacija u kojima se osoba našla, prije nego na njihove prediktore (Bond, 2004). Vodeći se tom pretpostavkom, neka istraživanja povezuju različite obrambene mehanizme s aleksitimijom, zbog čije se nemogućnosti opisivanja i identificiranja emocija kod pojedinca često pojavljuju nezreli obrambeni mehanizmi. Tako su Evren i sur. (2012) u svom istraživanju dokazali kako visoka razina aleksitimije predviđa češće korištenje nezrelih obrambenih mehanizama, a do sličnih su nalaza došli i drugi autori na različitim uzorcima (Bogutyn, Kokoszka, Palczinsky i Holas, 1999; Helmes, McNeill, Holden i Jackson, 2008; Besharat i Shahidi, 2011). Od pojedinih obrambenih mehanizama iz nezrelog obrambenog stila, s aleksitimijom su najčešće povezane autistične fantazije, somatizacija, projekcija i premještanje (Bogutyn i sur., 1999).

S obzirom na to da postoji mali broj sveobuhvatnih istraživanja kvalitete života kod žena oboljelih od raka dojke te je nedovoljno istražena uloga i utjecaj aleksitimije i obrambenih mehanizama na kvalitetu života, glavni je cilj ovog istraživanja utvrditi razinu kvalitete života kod pacijentica s karcinomom dojke s obzirom na izraženosti aleksitimije i korištenih obrambenih mehanizama. Također, specifični ciljevi ovog istraživanja bili su utvrditi povezanost aleksitimije i obrambenih mehanizama kod žena oboljelih od raka dojke te utvrditi razlike u učestalosti korištenja različitih obrambenih mehanizama s obzirom na razinu aleksitimije kod žena oboljelih od raka dojke.

\section{METODA}

\section{Sudionice}

U ovom je istraživanju korišten prigodan uzorak osoba ženskog spola s dijagnozom raka dojke, a koje su u vrijeme prikupljanja podataka potražile pomoć u nekoj od klinika ili udruga u gradu Zagrebu. U uzorak su uključene samo osobe (1) $\mathrm{s}$ dijagnozom raka dojke te (2) one osobe koje u vrijeme testiranja nisu primale lije- 
kove koji bi na bilo koji način mogli utjecati na psihičko stanje te osobe. Određeni broj upitnika čije su relevantne čestice ostale neodgovorene je uklonjen iz daljnje analize. Tako je broj sudionica uključenih u završni uzorak iznosio 44. Raspon dobi sudionica kretao se između 42 i 77 godina $(M=61,1$ uz $S D=8,65)$. Pri tome je 24 sudionica udano, dok su ostale rastavljene ili udovice. Većina sudionica živi u velikom gradu $(N=30)$ i ima djecu $(N=39)$. Velika većina sudionica ima završenu barem četverogodišnju srednju školu $(N=40)$. Njih 17 je zaposleno, dok su preostale u većini slučajeva umirovljene. Primarni tumor je dijagnosticiran kod 31 sudionice, kod 12 sudionica je bio dijagnosticiran i tumor regionalnih (ipsilateralni) limfnih čvorova, dok se kod samo jedne sudionice radi o udaljenim metastazama. Od dijagnoze raka kod sudionica je u prosjeku prošlo 7,25 godina. Sve su sudionice u nekom trenutku primale određenu onkološku terapiju.

\section{Instrumenti}

Za potrebe ovog istraživanja konstruiran je anketni upitnik koji se sastojao od sociodemografskih pitanja.

Upitnik zdravstvenog statusa (Short Form Health Survey - SF36) konstruirali su Ware i Sherbourne (1992), a koristi se kao mjera samoprocjene zdravstvenog stanja sudionika kroz 8 dimenzija: fizičko funkcioniranje, ograničenje zbog fizičkih poteškoća, tjelesni bolovi, percepcija općeg zdravlja, vitalnost, socijalno funkcioniranje, ograničenje zbog emocionalnih poteškoća, mentalno zdravlje. Sadrži i jednu česticu kojom se ispituje sudionikova percepcija pomaka u njegovu zdravstvenom stanju s obzirom na prošlu godinu. Sastoji se od 36 pitanja višestrukog izbora, čiji se odgovori različito boduju prema unaprijed utvrđenim normama. Na reprezentativnom uzorku stanovnika Republike Hrvatske koeficijenti pouzdanosti za sve dimenzije pokazali su se zadovoljavajućima te su se kretali između $\alpha=, 78$ do $\alpha=$ ,94 (Maslić Seršić i Vuletić, 2006).

Torontska skala aleksitimije (Toronto Alexithymia Scale - TAS-20; Bagby, Parker i Taylor, 1994). Osim što mjeri ukupnu razinu aleksitimije, skala sadrži i 3 subskale: poteškoće u opisivanju emocija, poteškoće u identificiranju emocija i eksternalno orijentirano mišljenje. Cijela se skala sastoji od 20 čestica na koje se odgovara na skali Likertova tipa od 1 ("Uopće se ne slažem") do 5 ("U potpunosti se slažem"). Koeficijent unutarnje konzistencije konstruirane skale iznosi $\alpha=, 833$.

Upitnik obrambenih stilova (Defense Style Questionnare-40) su razvili Andrews, Singh i Bond (1993). Upitnik mjeri hijerarhiju obrambenih stilova koji su proizašli iz psihoanalitičke teorije, odnosno pojedinčeve tipične načine suočavanja s različitim životnim poteškoćama. Ovaj se upitnik sastoji od 20 različitih obrambenih mehanizmima koji se mogu podijeliti u 3 šire skupine obrambenih stilova: Zreli mehanizmi obrane (sublimacija, anticipacija, humor i supresija), Neurotski mehanizmi obrane (negiranje, pseudoaltruizam, reaktivna formacija i idealizacija), 
Nezreli mehanizmi obrane (projekcija, pasivna agresija, acting out, izolacija, devaluacija, autistične fantazije, poricanje, premještanje, disocijacija, raščlanjivanje, racionalizacija i somatizacija). Svaku tvrdnju ispitanik procjenjuje s obzirom na čestinu pojavljivanja opisanih ponašanja u njegovu svakodnevnom životu na ljestvici od 1 ("Uopće se ne slažem") do 9 ("U potpunosti se slažem”). Koeficijenti unutarnje konzistencije tri obrambena tipa kretali su se između $\alpha=, 601$ i $\alpha=, 817$. Koeficijenti se mogu smatrati relativno prikladnim s obzirom na to da se u pojedinoj skupini nalazi više obrambenih mehanizama.

\section{Postupak}

Prije pristupanja provođenju istraživanja dobiveno je odobrenje Etičkog povjerenstva Hrvatskih studija Sveučilišta u Zagrebu za provedbu istraživanja. Pacijenticama koje boluju od raka dojke podijeljeni su papir-olovka upitnici te je prije rješavanja upitnika svim sudionicama objašnjeno kako je istraživanje u potpunosti anonimno i dobrovoljno te da su slobodne odustati od rješavanja upitnika u bilo kojem trenutku. Dodatno su zamoljene da potpišu informirani pristanak u kojem im je objašnjena svrha istraživanja te da svojim potpisom daju suglasnost o sudjelovanju $\mathrm{u}$ istraživanju i korištenju rezultata u znanstvene svrhe. U informiranom pristanku naveden je i kontakt istraživača na koji se sudionice mogu javiti ako ih zanimaju vlastiti rezultati. Anketiranje sudionica je provedeno primjenom papir-olovka upitnika, a samo je rješavanje upitnika u prosjeku trajalo oko 40 minuta.

\section{REZULTATI}

U svrhu provjere hipoteza istraživanja provedene su statističke analize podataka programskim paketom SPSS verzija 22.0 (IBM, 2013). Prikazani su deskriptivni podaci odgovora na pojedine skale te su korištene bivarijantne analize korelacija, univarijantna analiza varijance i hijerarhijska regresijska analiza.

Kao što je vidljivo iz Tablice 1., sudionice svoju kvalitetu života po različitim dimenzijama procjenjuju kao osrednju, budući da je najveća moguća vrijednost svake dimenzije 100. Od 8 dimenzija kvalitete života, najveću prosječnu vrijednost za sudionice ima dimenzija socijalnog funkcioniranja $(M=63,36 \mathrm{uz} S D=23,25)$, što označava da sudionice percipiraju kako je njihovo zdravstveno stanje najmanje utjecalo na njihov društveni život, dok se u općoj populaciji socijalno funkcioniranje u prosjeku procjenjuje još i boljim $(M=73,8$ uz $S D=27,8)$. Najmanju su prosječnu vrijednost na dimenzijama kvalitete života sudionice ostvarile na dimenziji ograničenja zbog fizičkih poteškoća $(M=39,53$ uz $S D=35,45)$, dok se parametri opće populacije kreću oko prosječne vrijednosti $M=69,1$ uz $S D=30,0$. Budući da su na ovoj dimenziji sudionice ostvarile najmanji prosječni rezultat, može se pretpostaviti kako sudionice smatraju da im je trenutačno zdravstveno stanje ponajviše 
Tablica 1. Deskriptivni podaci rezultata sudionika $(N=44)$ i njihove usporedbe kvalitete života s općom populacijom Republike Hrvatske $(N=9070$; Maslić Seršić i Vuletić, 2006)

\begin{tabular}{|c|c|c|c|c|c|c|}
\hline & $M\left(M_{p}\right)$ & $S D\left(S D_{p}\right)$ & Min. & Max. & $\begin{array}{l}\text { Zakrivlje- } \\
\text { nost }(z)\end{array}$ & $\begin{array}{l}\text { Spljošte- } \\
\text { nost }(z)\end{array}$ \\
\hline Dob & 61,10 & 8,65 & 42,00 & 77,00 & $-1,37$ &,- 29 \\
\hline $\begin{array}{l}\text { Vrijeme proteklo od } \\
\text { dijagnoze }\end{array}$ & 7,25 & 5,49 & 1,00 & 26,00 & $3,17^{*}$ & $2,55^{*}$ \\
\hline Fizičko funkcioniranje & $\begin{array}{c}52,74 \\
(69,1)\end{array}$ & $\begin{array}{r}23,44 \\
(30,0)\end{array}$ & 5,00 & 100,00 &,- 36 &,- 68 \\
\hline $\begin{array}{l}\text { Ograničenje zbog fizičkih } \\
\text { poteškoća }\end{array}$ & $\begin{array}{c}39,53 \\
(61,5)\end{array}$ & $\begin{array}{r}35,45 \\
(44,8)\end{array}$ & ,00 & 100,00 & ,61 & $-1,94$ \\
\hline $\begin{array}{l}\text { Ograničenje zbog } \\
\text { emocionalnih poteškoća }\end{array}$ & $\begin{array}{l}48,06 \\
(68,6)\end{array}$ & $\begin{array}{r}36,59 \\
(43,7)\end{array}$ &, 00 & 100,00 &,- 20 & $-1,86$ \\
\hline Vitalnost & $\begin{array}{r}48,53 \\
(53,2)\end{array}$ & $\begin{array}{r}21,91 \\
(22,7)\end{array}$ & ,00 & 100,00 &,- 05 &, 57 \\
\hline Mentalno zdravlje & $\begin{array}{c}62,70 \\
(61,9)\end{array}$ & $\begin{array}{r}18,31 \\
(21,4)\end{array}$ & 8,00 & 100,00 &,- 69 & 1,07 \\
\hline Socijalno funkcioniranje & $\begin{array}{r}63,35 \\
(73,8)\end{array}$ & $\begin{array}{r}23,25 \\
(27,8)\end{array}$ &, 00 & 100,00 & $-1,50$ &, 23 \\
\hline Tjelesni bolovi & $\begin{array}{l}60,06 \\
(64,6)\end{array}$ & $\begin{array}{l}21,96 \\
(30,5)\end{array}$ &, 00 & 100,00 &,- 78 &, 14 \\
\hline Percepcija općeg zdravlja & $\begin{array}{r}53,32 \\
(54,8)\end{array}$ & $\begin{array}{l}19,76 \\
(22,6)\end{array}$ & 15,00 & 100,00 & 1,84 & ,62 \\
\hline Aleksitimija & 51,65 & 12,56 & 24,00 & 79,00 &, 11 &,- 12 \\
\hline Zreli obrambeni stil & 5,86 & 1,53 & 2,75 & 9,00 &,- 17 &,- 82 \\
\hline Neurotski obrambeni stil & 5,56 & 1,36 & 3,00 & 8,63 & 0,04 &,- 46 \\
\hline Nezreli obrambeni stil & 4,26 & 1,15 & 2,00 & 7,92 & 1,84 & 1,58 \\
\hline
\end{tabular}

* - $p<, 05 ; M_{p}$ - prosječna vrijednost pojedinih dimenzija kvalitete života u populaciji; $S D_{p}=$ standardna devijacija pojedinih dimenzija kvalitete života u populaciji

utjecalo na svakodnevni život upravo preko tjelesnih poteškoća koje su pratile dijagnozu raka dojke. Ipak, valja naglasiti kako prosječna vrijednost ni jedne dimenzije kvalitete života ne prelazi $M=63,36$, što ne bi trebalo biti zadovoljavajuće, pogotovo uzevši u obzir prosječno vrijeme koje je proteklo od dijagnoze raka dojke kod sudionica.

Prosječna vrijednost na skali aleksitimije kod sudionica iznosi $M=51,65$ uz $S D$ $=12,56$, što na grupnoj razini označava moguću aleksitimiju. Sudionice u najvećoj mjeri upotrebljavaju zrele obrambene mehanizme $(M=5,86 \mathrm{uz} S D=1,53)$, zatim neurotske ( $M=5,56 \mathrm{uz} S D=1,36)$, a najmanje se oslanjaju na nezreli tip obrambenih mehanizama $(M=4,26$ uz $S D=1,15)$.

Tablica 2. Korelacije 8 dimenzija kvalitete života s drugim relevantnim varijablama istraživanja $(N=44)$ 


\begin{tabular}{|c|c|c|c|c|c|c|c|c|}
\hline & 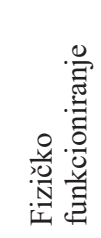 & 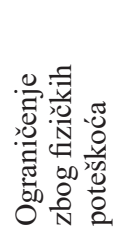 & 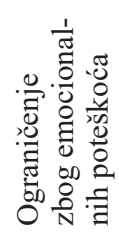 & 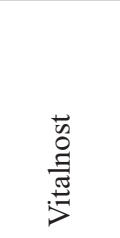 & 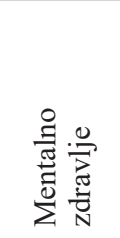 & 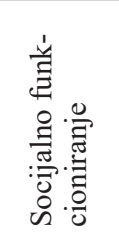 & \begin{tabular}{l}
$\vec{z}$ \\
$\stackrel{5}{0}$ \\
$\stackrel{0}{0}$ \\
\hdashline 8
\end{tabular} & 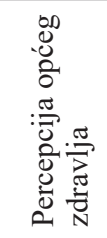 \\
\hline Dob & ,059 & ,190 & ,296 & ,393* & ,292 & ,377* & ,122 &,- 043 \\
\hline $\begin{array}{l}\text { Vrijeme proteklo } \\
\text { od dijagnoze }\end{array}$ &,- 033 &,- 027 & 045 & ,079 & ,246 &, 074 &,- 041 &,- 013 \\
\hline Aleksitimija & 021 &,$- 398 * *$ &,$- 465 * *$ &,$- 607 * *$ &,$- 678^{* *}$ &,$- 538^{* *}$ &,$- 475^{* *}$ &,$- 617 * *$ \\
\hline $\begin{array}{l}\text { Zreli } \\
\text { obrambeni stil }\end{array}$ &,- 054 & ,399** &, $420 * *$ & ,202 & ,239 & ,281 & 089 & ,147 \\
\hline $\begin{array}{l}\text { Neurotski } \\
\text { obrambeni stil }\end{array}$ & ,605 & ,117 &, 046 &, 057 &, 074 & , 140 & ,119 &,- 108 \\
\hline $\begin{array}{l}\text { Nezreli } \\
\text { obrambeni stil }\end{array}$ & ,122 &,- 091 &,- 122 &,- 129 &,- 165 &,- 070 &,- 209 &,- 173 \\
\hline
\end{tabular}

$*-p<.05 ; * *-p<.01$

Najveće korelacije su uočene između dimenzija kvalitete života i aleksitimije, pri čemu je aleksitimija umjereno statističko značajno negativno povezana s dimenzijom percipiranog općeg zdravlja i mentalnog zdravlja. Aleksitimija općenito negativno korelira s različitim dimenzijama kvalitete života, što upućuje na općenito sniženu kvalitetu u različitim životnim domenama kod osoba koje pate od aleksitimije. Od obrambenih stilova, s dimenzijama kvalitete života značajno je pozitivno korelirao jedino zreli obrambeni stil, gdje osobe koje češće upotrebljavaju mehanizme ovog stila percipiraju znatno manja ograničenja zbog emocionalnih $(r=, 420) i$ fizičkih $(r=, 399)$ poteškoća, dok se korelacije neurotskog i nezrelog obrambenog stila s dimenzijama kvalitete života nisu pokazale značajnima.

Može se zamijetiti (Tablica 3) kako u većini slučajeva ni dob sudionica ni vrijeme koje je proteklo od dijagnoze raka dojke, ne korelira značajno s ukupnom aleksitimijom, kao ni s njene 3 subskale, što ide u prilog rezultatima ranijih istraživanja koja smatraju da je aleksitimiju pravilnije promatrati kao stabilnu karakteristiku osobe nego kao njeno prolazno stanje (Lumley i sur., 2007). Značajna niska pozitivna korelacija je dobivena jedino između dobi sudionica i subskale eksternalno orijentiranog mišljenja $(r=, 338)$. Ako promatramo eksternalno orijentirano mišljenje kao sadržaj mišljenja koji je vođen pravilima, regulacijama i svakodnevnim zadacima umjesto emocijama, jasno je kako se takav kognitivni stil pojavljuje češće kod starijih, u većini slučajeva emocionalno zrelijih osoba.

Kako bi se utvrdilo postoje li razlike u učestalosti korištenja određenih obrambenih mehanizama i cjelokupnih obrambenih stilova kod tri grupe sudionica (sudionice bez aleksitimije, sudionice s mogućom aleksitimijom i sudionice s aleksiti- 
Tablica 3. Korelacije ukupnog rezultata na skali aleksitimije i njene tri subskale s drugim relevantnim varijablama istraživanja $(N=44)$

\begin{tabular}{lcccc}
\hline & $\begin{array}{c}\text { Teškoće } \mathrm{u} \\
\text { opisivanju } \\
\text { emocija }\end{array}$ & $\begin{array}{c}\text { Teškoće u } \\
\text { identificiranju } \\
\text { emocija }\end{array}$ & $\begin{array}{c}\text { Eksternalno } \\
\text { orijentirano } \\
\text { mišljenje }\end{array}$ & $\begin{array}{c}\text { Ukupni rezultat } \\
\text { na skali } \\
\text { aleksitimije }\end{array}$ \\
\hline Dob &,- 006 &, 030 &, $338^{*}$ &, 111 \\
$\begin{array}{l}\text { Vrijeme proteklo od } \\
\text { dijagnoze }\end{array}$ &,- 181 &,- 125 &,- 016 &,- 119 \\
$\begin{array}{l}\text { Zreli obrambeni stil } \\
\begin{array}{l}\text { Neurotski } \\
\text { obrambeni stil }\end{array}\end{array}$ &,- 094 &, 105 &, 145 &,- 020 \\
$\begin{array}{l}\text { Nezreli } \\
\text { obrambeni stil }\end{array}$ &, 266 &, 146 &, 179 &, 200 \\
\hline$* p<.05 ; * * p<.01$ &, $443 *$ &, $306 *$ &, 115 &, $410^{* *}$ \\
& & & &
\end{tabular}

mijom), provedena je analiza varijance (ANOVA). Prema navođenju autora skale TAS-20 (Bagby i sur., 1994) sudionice koje su postigle rezultat na skali manji od 50 su svrstane u skupinu "bez aleksitimije", sudionice čiji su rezultati bili između 51 i 60 su svrstane u skupinu "moguća aleksitimija", a sudionice koje su imale rezultat veći do 60 su svrstane u skupinu "aleksitimija".

U Tablici 4 prikazani su rezultati razlike u učestalosti korištenja pojedinih obrambenih mehanizama i tri obrambena stila s obzirom na razinu aleksitimije 3 grupe sudionica. Može se zamijetiti kako se grupe sudionica razlikuju jedino u učestalosti korištenja nezrelog obrambenog stila $(F(2,41)=4,358, p=, 019)$, dok zreli i neurotski obrambeni stil sve sudionice pokazuju u podjednakoj mjeri. LSD post-hoc test pokazao je kako sudionice s aleksitimijom i sudionice s mogućom aleksitimijom imaju značajno više izražen nezreli obrambeni stil prilikom nošenja sa stresnim situacijama od sudionica bez aleksitimije.

Od pojedinih obrambenih mehanizama nezrelog obrambenog stila značajne su razlike nađene $\mathrm{u}$ korištenju pasivne agresije $(p=, 025)$, izolacije $(p=, 005)$, autističnih fantazija $(p=0,01)$ i splittinga $(p=0,019)$, dok rubnu značajnost pokazuje obrambeni mehanizam somatizacije $(p=, 056)$. LSD post-hoc testom je dokazano kako se značajne razlike u korištenju spomenutih obrambenih mehanizama pojavljuju između skupine bez aleksitimije i skupine s mogućom aleksitimijom za pasivnu agresiju $(p=, 007)$ i splitting $(p=, 004)$. Sudionice s mogućom aleksitimijom izvještavaju o učestalijem korištenju pasivne agresije i splittinga. Nadalje, nađene su razlike između skupine bez aleksitimije i skupine s aleksitimijom za autistične fantazije ( $p=, 003)$, na način da osobe s aleksitimijom u većoj mjeri upotrebljavaju autistične fantazije od osoba koje ne zadovoljavaju kriterije za dijagnozu aleksitimije. Obrambeni mehanizam izolacije statistički značajno više upotrebljavaju osobe 


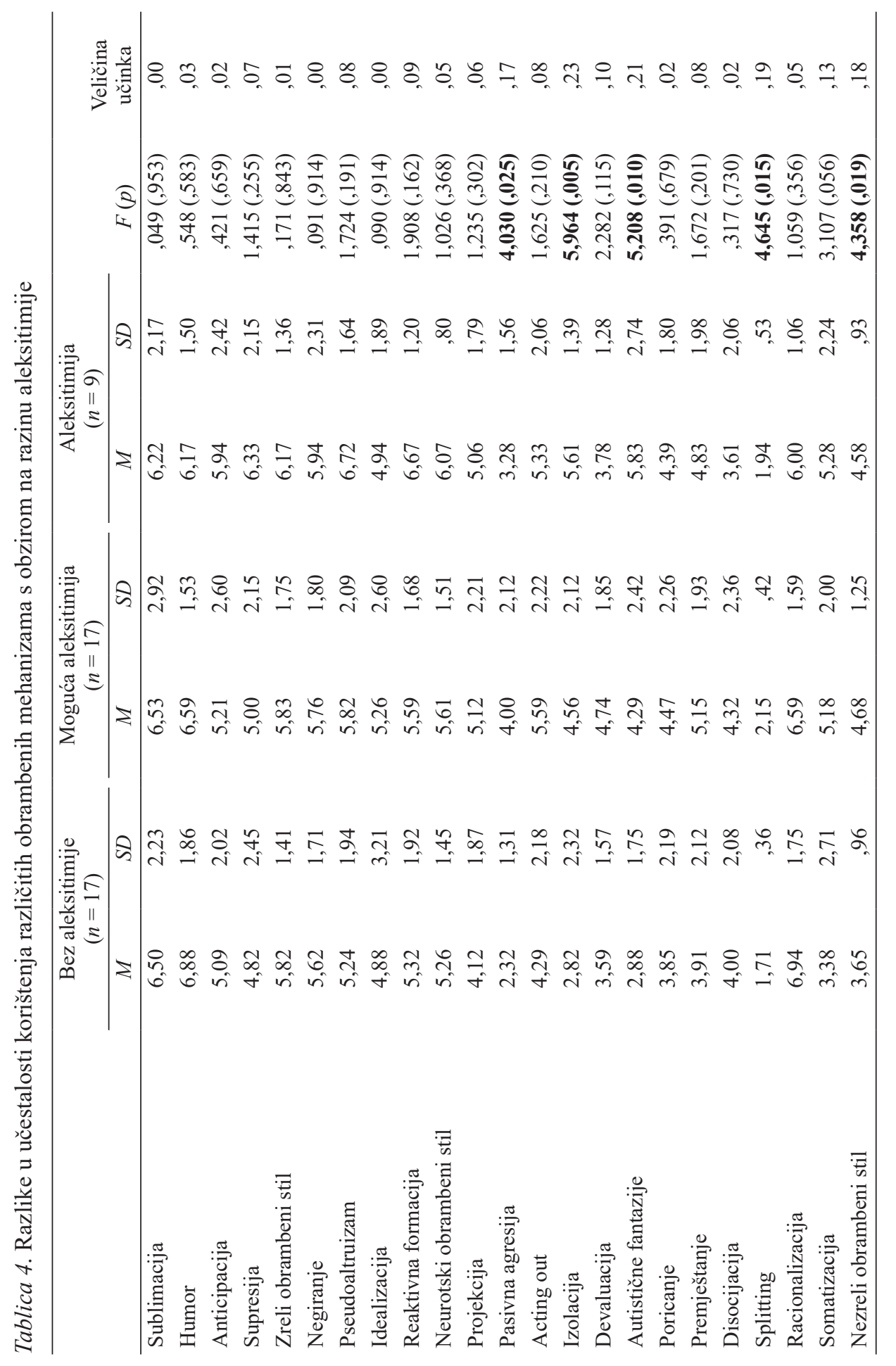


Tablica 5. Prikaz rezultata linearne regresije te standardiziranih koeficijenata analiziranih prediktora 8 dimenzija kvalitete života i testiranje njihove značajnosti

\begin{tabular}{|c|c|c|c|c|c|c|c|c|}
\hline Kriteriji & Prediktori & & $R$ & $R^{2}$ & $R_{c o} r 2$ & $\Delta \mathrm{R}^{2}$ & $\beta$ & $p$ \\
\hline \multirow{4}{*}{$\begin{array}{l}\text { Fizičko } \\
\text { funkcioniranje }\end{array}$} & \multicolumn{2}{|l|}{ Aleksitimija } & , 197 & ,039 &,- 062 & ,039 &,- 015 & $>, 05$ \\
\hline & \multirow{3}{*}{$\begin{array}{l}\text { Obrambeni } \\
\text { stilovi }\end{array}$} & Nezreli & & & & & ,112 & $>, 05$ \\
\hline & & Neurotski & & & & & , 141 & $>, 05$ \\
\hline & & Zreli & & & & &,- 172 & $>, 05$ \\
\hline \multirow{4}{*}{$\begin{array}{l}\text { Ograničenje } \\
\text { zbog fizičkih } \\
\text { poteškoća }\end{array}$} & \multicolumn{2}{|l|}{ Aleksitimija } &, $537 * *$ &, $289 * *$ &, $214 * *$ &, $289 * *$ &,- 229 & $>, 05$ \\
\hline & Obrambeni & Nezreli & & & & &,- 208 & $>, 05$ \\
\hline & stilovi & Neurotski & & & & &,- 045 & $>, 05$ \\
\hline & & Zreli & & & & &, $524 * *$ & $<, 01$ \\
\hline \multirow{4}{*}{$\begin{array}{l}\text { Ograničenje } \\
\text { zbog } \\
\text { emocionalnih } \\
\text { poteškoća }\end{array}$} & \multirow{4}{*}{$\begin{array}{l}\text { Aleksitimija } \\
\text { Obrambeni } \\
\text { stilovi }\end{array}$} & &, $624 * *$ &, $389 * *$ &, $325 * *$ &, $389 * *$ &,$- 346 * *$ & $<, 01$ \\
\hline & & Nezreli & & & & &,- 236 & $>, 05$ \\
\hline & & Neurotski & & & & & ,003 & $>, 05$ \\
\hline & & Zreli & & & & &, $539 * *$ & $<, 01$ \\
\hline \multirow[t]{4}{*}{ Vitalnost } & \multirow{4}{*}{$\begin{array}{l}\text { Aleksitimija } \\
\text { Obrambeni } \\
\text { stilovi }\end{array}$} & &, $487 *$ &, $238^{*}$ &, $157 *$ &, $238^{*}$ &,$- 398 * *$ & $<, 01$ \\
\hline & & Nezreli & & & & &,- 164 & $>, 05$ \\
\hline & & Neurotski & & & & & ,153 & $>, 05$ \\
\hline & & Zreli & & & & & ,213 & $>, 05$ \\
\hline \multirow{4}{*}{$\begin{array}{l}\text { Mentalno } \\
\text { zdravlje }\end{array}$} & \multirow{4}{*}{$\begin{array}{l}\text { Aleksitimija } \\
\text { Obrambeni } \\
\text { stilovi }\end{array}$} & & ,666** &, $444 * *$ &, $387 * *$ &, $444 * *$ &,$- 551 * *$ & $<, 01$ \\
\hline & & Nezreli & & & & &,- 245 & $>, 05$ \\
\hline & & Neurotski & & & & & ,284 & $>, 05$ \\
\hline & & Zreli & & & & & ,230 & $>, 05$ \\
\hline \multirow{4}{*}{$\begin{array}{l}\text { Socijalno } \\
\text { funkcioniranje }\end{array}$} & \multirow{4}{*}{$\begin{array}{l}\text { Aleksitimija } \\
\text { Obrambeni } \\
\text { stilovi }\end{array}$} & &, $553 * *$ &, $306^{* *}$ &, $235 * *$ &, $306 * *$ &,$- 451 * *$ & $<, 01$ \\
\hline & & Nezreli & & & & &,- 119 & $>, 05$ \\
\hline & & Neurotski & & & & & ,136 & $>, 05$ \\
\hline & & Zreli & & & & & ,289 & $>, 05$ \\
\hline \multirow[t]{4}{*}{ Tjelesni bolovi } & \multirow{4}{*}{$\begin{array}{l}\text { Aleksitimija } \\
\text { Obrambeni } \\
\text { stilovi }\end{array}$} & & ,457 & ,209 & , 127 & ,209 & $-.378 *$ & $<.05$ \\
\hline & & Nezreli & & & & & -.131 & $>.05$ \\
\hline & & Neurotski & & & & & -.049 & $>.05$ \\
\hline & & Zreli & & & & & .193 & $>.05$ \\
\hline \multirow{4}{*}{$\begin{array}{l}\text { Percepcija } \\
\text { općeg zdravlja }\end{array}$} & \multirow{4}{*}{$\begin{array}{l}\text { Aleksitimija } \\
\text { Obrambeni } \\
\text { stilovi }\end{array}$} & &, $561 * *$ &, $315^{* *}$ &, $245 * *$ &, $315^{* *}$ & $-.507 * *$ & $<.01$ \\
\hline & & Nezreli & & & & & -.132 & $>.05$ \\
\hline & & Neurotski & & & & & .087 & $>.05$ \\
\hline & & Zreli & & & & & .190 & $>.05$ \\
\hline
\end{tabular}

$* p<, 05 ; * * p<, 01$ 
s mogućom aleksitimijom $(p=0,02)$ i osobe $\mathrm{s}$ razvijenom aleksitimijom $(p=, 002)$ od onih koje nemaju simptome aleksitimije.

Rezultati linearne regresijske analize po pojedinim dimenzijama kvalitete života prikazani su u Tablici 5. Model se nije pokazao značajnim za predviđanje tek jedne dimenzije kvalitete te je kombinirani doprinos aleksitimije i obrambenih mehanizama bio neznačajan kod kriterija tjelesnih bolova i fizičkog funkcioniranja. Ostale su dimenzije kvalitete života značajno objašnjene u provedbi regresijske analize, pri čemu se jasno uviđa da je od dvije varijable bolji prediktor aleksitimija, dok se unutar obrambenih mehanizama značajnim prediktorom pokazao samo zreli obrambeni stil i to u slučaju ograničenja zbog fizičkih poteškoća i ograničenja zbog emocionalnih poteškoća i to na razini $p<, 01$.

Po dimenzijama kvalitete života, aleksitimija se pokazala najboljim prediktorom mentalnog zdravlja $(p<, 01)$ i percepcije općeg zdravlja $(p<, 01)$, dok je u slučajevima fizičkog funkcioniranja i ograničenja zbog fizičkih poteškoća pokazala neznačajnu prediktivnu ulogu. Zaključno, aleksitimija se generalno pokazala boljim prediktorom dimenzija kvalitete života pacijentica s rakom dojke od dimenzija obrambenih mehanizama.

\section{RASPRAVA}

Istraživanje je pokazalo kako žene oboljele od raka dojke imaju smanjenu kvalitetu života na pojedinim ispitanim dimenzijama. Sudionice su u prosjeku procjenjivale ograničenja zbog fizičkog funkcioniranja ispod $40 \%$, pri čemu bi $100 \%$ označavalo kako sudionice ne procjenjuju da nemaju nikakva ograničenja zbog fizičkog funkcioniranja. Time je jasno da je kvaliteta života osoba koje boluju od raka dojke ponajviše narušena upravo u tom segmentu. Ograničenja zbog emocionalnih poteškoća, vitalnost, fizičko funkcioniranje te percepciju općeg zdravlja sudionice procjenjuju tek nešto više, s prosječnim vrijednostima oko $50 \%$, čime se utvrđuje kako su ti aspekti kvalitete života sudionica i dalje prilično niski, što je u skladu s istraživanjem Fortner i suradnika (2002). Najviše su rezultate sudionice ostvarile na dimenzijama tjelesne boli, mentalnog zdravlja te socijalnog funkcioniranja, upućujući na najbolje funkcioniranje sudionica na upravo tim dimenzijama kvalitete života. Ovakvi su rezultati ohrabrujući te bi mogli upućivati na vrlo dobru socijalnu podršku pacijentica, što postavlja dobar temelj za daljnji napredak liječenja, sudeći po rezultatima ranijih istraživanja Fortner i suradnika (2002). Štoviše, usporedimo li ove rezultate s hrvatskim normama SF-36 upitnika, može se zaključiti kako je kvaliteta života žena koje su oboljele od raka dojke generalno snižena u odnosu na prosjek zemlje. Najveća se razlika pritom očitava u dimenzijama fizičkog funkcioniranja, ograničenja zbog fizičkih poteškoća te ograničenja zbog emocionalnih poteškoća (Maslić Seršić i Vuletić, 2006).

Aleksitimija se pokazala boljim prediktorom u objašnjenju kvalitete života kod pacijentica oboljelih od raka dojke u odnosu na obrambene stilove. Štoviše, pokaza- 
lo se kako je aleksitimija najbolji prediktor percepcije općeg zdravlja u tom modelu, a ovakvi nalazi nude mogućnost tumačenja visoke prediktivne snage aleksitimije u procjeni subjektivnog zdravlja kao svojevrsne adaptacije zbog nemogućnosti izražavanja emocionalnog stanja, pri čemu prepoznavanje somatskih simptoma može biti svojevrsna kompenzacija u nedostatku prepoznavanju tuđih i vlastitih emocionalnih stanja. Lumley, Neely i Burger (2007) dodaju kako razlog aleksitimične "sposobnosti" predviđanja vlastitog subjektivnog zdravlja predstavlja nerazlikovanje somatskih smetnji od fizioloških posljedica emocija.

Pronađene su razlike u učestalosti korištenja nezrelog obrambenog stila kod različitih grupa sudionica s obzirom na razinu aleksitimije, što je u skladu s nekim ranijim istraživanjima (Bogutyn i sur., 1999; Helmes i sur., 2008; Besharat i Shahidi, 2011). Razlike su također nađene u korištenju pojedinih obrambenih mehanizama nezrelog stila, kao što je pasivna agresija, izolacija, autistične fantazije i splitting ("crno-bijelo" odnosno "ili-ili" pogled na sebe i svijet koji osobu okružuje). Među nezrelim obrambenim mehanizmima posebice se ističe učestalost izolacije kod pacijentica s višim razinama aleksitimije, što je u skladu s istraživanjem Stanton i Snider (1993) koje opisuje strategije pacijentica prema kognitivnom izbjegavanju i socijalnoj distanciranosti u procesu tretmana karcinoma. Takvo izbjegavanje je prema istraživanju negativno povezano s pozitivnim ishodom bolesti te je ovaj rezultat direktno primjenjiv u svakodnevnoj psihološkoj praksi savjetovanja pacijentica koje boluju od raka dojke. Neki autori čak smatraju da bi izolacija za posljedicu mogla imati razvitak aleksitimičnih simptoma (Baumeister, Dale i Sommer, 1998), što bi bilo zanimljivo provjeriti u budućim istraživanjima ove tematike upravo kod žena koje boluju od raka dojke, budući da ih sama dijagnoza nerijetko prisiljava na povlačenje iz dotadašnjih socijalnih mreža.

Nadalje, neurotski obrambeni stilovi u analizi nisu pokazali značajnu povezanost s ostatkom varijabli, što nije u skladu s istraživanjem Cooper i Faragher (1993). Također, istraživanjem se nije potvrdila povezanost korištenja relativno štetnog mehanizma poput negiranja vlastitog stanja s procjenom kvalitete života na hrvatskom uzorku pacijentica s rakom dojke. Takav rezultat može se pripisati i vremenu odmaka od početne dijagnoze koje je za neke pacijentice moglo blagotvorno djelovati na uporabu zrelijih mehanizama obrane.

\section{Ograničenja i daljnje implikacije istraživanja}

Sudionici ovog istraživanja su iz populacije ženskih osoba s rakom dojke odabrani u uzorak neprobabilističkim putem zbog čega se treba s oprezom pristupiti generalizaciji njihovih rezultata na širu populaciju. Buduća bi istraživanja svakako trebala nastojati povećati uzorak pacijentica s rakom dojke te ga proširiti na ostale dijelove Republike Hrvatske i uključiti kontrolne skupine kako bi se omogućila usporedba rezultata dvije skupine po pojedinim dimenzijama kvalitete 
života. S obzirom na to da je uloga aleksitimije i obrambenih mehanizama u objašnjenju kvalitete života kod oboljelih od raka dojke prilično neistražena, postoji još puno mjesta za napredak, osobito za provedbu longitudinalnih istraživanja na ovu temu. Implikacije ovog istraživanja mogu imati dalekosežne posljedice i na tretman liječenja pacijentica s rakom dojke te bi fokus psihoterapije mogao postati socijalni trening emocionalnog izražavanja te prepoznavanja emocija i što bi moglo direktno i indirektno djelovati na poboljšanje određenih dimenzija kvalitete života pacijentica.

\section{ZAKLJUČAK}

U ovom je istraživanju cilj bio istražiti različite dimenzije kvalitete života kod pacijentica koje boluju od raka dojke te utvrditi ulogu obrambenih mehanizama i aleksitimije u predviđanju tih dimenzija. Rezultati su pokazali kako sudionice najviše ograničenja doživljavaju zbog različitih fizičkih poteškoća koje se pojavljuju u procesu liječenja od spomenute dijagnoze. Odmah zatim slijede ograničenja zbog emocionalnih poteškoća te vitalnost kao najviše pogođene dimenzije kvalitete života trenutačnim stanjem pacijentica. Aleksitimija se pokazala najboljim prediktorom percepcije općeg zdravlja, uočena je veća učestalost korištenja nezrelih obrambenih mehanizama kod pacijentica s aleksitimijom u usporedbi s pacijenticama s niskim razinama aleksitimije. Također je utvrđeno kako pacijentice s povišenim razinama aleksitimije u stresnim situacijama češće upotrebljavaju pasivnu agresiju, izolaciju, autistične fantazije i splitting od ostalih pacijentica.

\section{LITERATURA}

Andrews, G., Singh, M. i Bond, M. (1993). The Defense Style Questionnaire. The Journal of nervous and mental disease, 181(4), 246-256.

Bagby, R., Parker, J. D. i Taylor, G. J. (1994). The twenty-item Toronto Alexithymia scale I. Item selection and cross-validation of the factor structure. Journal of Psychosomatic Research, 38(1), 23-32.

Baumeister, R. F., Dale, K. i Sommer, K. L. (1998). Freudian Defense Mechanisms and Empirical Findings in Modern Social Psychology: Reaction Formation, Projection, Displacement, Undoing, Isolation, Sublimation, and Denial. Journal of Personality, 66, 1090-1092.

Besharat, M. A. i Shahidi, S. (2011). What is the relationship between alexithymia and ego defense styles? A correlational study with Iranian students. Asian Journal of Psychiatry, 4(2), 145-149.

Bogutyn, T., Kokoszka, A. Pałczyński, J., i Holas, P. (1999). Defense mechanisms in alexithymia. Psychological Reports, 84(1), 183-187. 
Bond, M. (2004). Empirical Studies of Defense Style: Relationships with Psychopathology and Change. Harvard Review of Psychiatry, 12(5), 263-278.

Cooper, C. L. i Faragher, E. B. (1993). Psychosocial stress and breast cancer: the inter-relationship between stress events, coping strategies and personality. Psychological Medicine, 23(3), 653-662.

De Vries, A. M., Forni, V., Voellinger, R. i Stiefel, F. (2012). Alexithymia in cancer patients: review of the literature. Psychotherapy Psychosomatic, 81(2), 79-86.

Evren, C., Cagil, D., Ulku, M., Ozcetinkaya, S., Gokalp, P., Cetin, T. i Yigiter, S. (2012). Relationship between defense styles, alexithymia, and personality in alcohol-dependent inpatients. Comprehensive Psychiatry, 53(6), 860-867.

Fortner, B. V., Stepanski, E. J., Wang, S. C., Kasprowicz, S. i Durrence, H. H. (2002). Sleep and quality of life in breast cancer patients. Pain Symptom Manage, 24(5), 471-480.

Helmes, E., McNeill, P. D., Holden, R. R. i Jackson, C. (2008). The construct of alexithymia: Associations with defense mechanisms. Journal of Clinical Psychology, 64(3), 318331.

Hrvatski zavod za javno zdravstvo. (2016). Hrvatski zdravstveno-statistički ljetopis za 2015. godinu. Zagreb: Hrvatski zavod za javno zdravstvo.

Lumley, M. A., Neely, L. C. i Burger, A. J. (2007). The assessment of alexithymia in medical settings: implications for understanding and treating health problems. Journal of Personal Assessment, 89(3), 230-246.

Maslić Seršić, D. i Vuletić, G. (2006). Psychometric evaluation and establishing norms of Croatian SF-36 health survey: framework for subjective health research. Croatian Medical Journal, 47(1), 95-102.

Mosher, C. E., Johnson, C., Dickler, M., Norton, L., Massie, M. J. i DuHamel, K. (2013). Living with metastatic breast cancer: a qualitative analysis of physical, psychological, and social sequelae. Breast Journal, 19(3), 285-292.

Perry, S., Kowalski, T. L. i Chang, C. (2007). Quality of life assessment in women with breast cancer: Benefits, acceptability and utilization. Health and Quality of Life Outcomes, 5(1), 24.

Porcelli, P., Tulipani, C., Maiello, E., Cilenti, G. i Todarello, O. (2007). Alexithymia, coping, and illness behavior correlates of pain experience in cancer patients. Psychooncology, 16(7), 644-650.

Stanton, A. L. i Snider, P. R. (1993). Coping with a breast cancer diagnosis: a prospective study. Health Psychology, 12(1), 16-23.

Ware, J. E. i Sherbourne, C. D. (1992). The MOS 36-item Short-Form Health Survey (SF36). I. Conceptual Framework and Item Selection. Medical Care 30(6), 473-483.

World Cancer Research Fund International (2014). Pribavljeno 26.4. 2018. godine s adrese https://www.wcrf.org/int/cancer-facts-figures/worldwide-data. 


\title{
QUALITY OF LIFE FOR PATIENTS WITH BREAST CANCER: THE ROLE OF ALEXITHYMIA AND DEFENSE MECHANISMS
}

\begin{abstract}
Summary
Patients who suffer from breast cancer often experience various mental issues, due to the diagnosis itself and its outcomes. The main purpose of this study is to determine the quality of life and certain psychological aspects of patients with breast cancer in Croatia. Forty-four patients diagnosed with breast cancer (mean age 61.1 years), who sought help in various clinics and organizations in Zagreb, were involved in this study. A self-assessment questionnaire consisted of the socio-demographic part and three clinical scales: Toronto Alexithymia Scale (TAS-20), Defense Style Questionnaire (DSQ-40) and Short Form Health Survey (SF36).

Results indicate low quality of some aspects of the patient's lives, while linear regression analysis showed alexithymia to be a major predictor of various dimensions of life quality. Furthermore, alexithymia was a significant predictor in determining the perception of general health among patients suffering from breast cancer, and it has shown a greater incidence of using various immature defense mechanisms in patients with alexithymia. A more detailed explanation of these results, as well as implications for further research, are discussed.
\end{abstract}

Key words: breast cancer, quality of life, alexithymia, defense mechanisms

Primljeno: 25. 10. 2019. 
